\title{
Effect of pH on Dissimilatory Sulfate Reduction by Porcine Cecal Microflora
}

\author{
Kazunari USHIDA, Sinya FUKUSADA \\ and Yoichi KOJIMA \\ Laboratory of Animal Science, Kyoto Prefectural University, \\ Shimogamo, Sakyo-ku, Kyoto-shi 606-8522
}

(Received January 21, 1998)

\begin{abstract}
The pH optima of dissimilatory sulfate reduction by porcine cecal microflora were determined. Digesta were sampled from a cecally fistulated pig and washed bacterial cell suspensions were prepared. They were incubated in anaerobic culture tubes under nitrogen atmosphere with $20 \mathrm{mM}$ sulfate and an electron donor for $12 \mathrm{~h}$ at $37^{\circ} \mathrm{C}$. Either hydrogen $(100 \% \mathrm{in}$ head space gas) or lactate $(50 \mathrm{mM})$ was used as the electron donor. The initial culture $\mathrm{pH}$ was adjusted to 14 levels from 4.5 to 7.4. Hydrogen sulfide concentration in the head space gas was determined at the end of incubation by FPD (flame photometric detector)-gas chromatography after addition of $6 \mathrm{~N} \mathrm{HCl}$ to the culture. Organic acids were determined by ion exclusion HPLC. The $\mathrm{pH}$ optimum for hydrogen sulfide production with hydrogen was as low as 6.0 and those with lactate placed between 6.1 and 6.4. The $\mathrm{pH}$ optimum for lactate consumption was slightly lower than that for hydrogen sulfide production, while that for acetate production was close to that for hydrogen sulfide production.
\end{abstract}

Anim. Sci. Technol. (Jpn.) 69 (6) : 571-575, 1998

Key words : Dissimilatory sulfate reduction, Cecal microflora, $\mathrm{pH}$ optima, Pig

Dissimilatory sulfate reduction is one of the major electron disposals in the large intestine of human and pig ${ }^{1,15)}$. Although sulfate reduction is an important metabolic process for anaerobic microfiora, providing an electron sink for fermentative hydrogen producers, the resultant hydrogen sulfide is toxic ${ }^{12)}$ and a relationship with colonic ulcerative colitis has been suggested ${ }^{6)}$. Accordingly the importance of controlling hydrogen sulfide production in the large intestine has been stressed ${ }^{77}$.

Colonic sulfate reduction was shown to increase when turnover of digesta was low under neutral to weakly alkaline conditions in a multiple vessel-continuous culture experiment ${ }^{5)}$. The results appeared to be consistent with those reviewed by Pfennig et al. ${ }^{11)}$ who indicated that sulfate reducing bacteria (SRB) grew well under slightly alkaline conditions (pH 7.0-7.8). However, research on sudden death victims suggested that colonic sulfate reduction was most active in the ascending and transverse colons ${ }^{9)}$ where the usual digesta $\mathrm{pH}$ ranges from 5.4 to 6.2 due to short chain fatty acid production ${ }^{2}$. The effect of $\mathrm{pH}$ on dissimilatory sulfate reduction is still controversial ${ }^{4)}$. Tuttle et al. ${ }^{14)}$ reported that sulfate reduction occurred even in a highly acidic environment ( $\mathrm{pH} 3.0$ ), although the strains of SRB isolated, belonging to the genera Desulfovibrio and Desulfotomaculum, could not reduce sulfate when $\mathrm{pH}$ was below 5.5. The effect of milieu $\mathrm{pH}$ on sulfate reduction is further complicated by the electron donors. Thus hydrogen gas oxidation with sulfate anion requires a proton, whereas oxidative 
decarboxylation of lactate coupled with sulfate reduction releases a proton (see below).

The present experiment was therefore conducted to determine the $\mathrm{pH}$ optima of sulfate reduction with two major electron donors, hydrogen and lactate, in the hind gut of pig.

\section{Materials and Methods}

A cecally-fistulated, Large $W$ hite $\times$ Landrace cross-bred female pig ( $\mathrm{BW}=110 \mathrm{~kg}$ ) was used as a donor of cecal digesta. The pig was fed $1,000 \mathrm{~g}$ commercial concentrate free from antibiotics (Ultrabreed 72, Kumiai Shiryo Co., Kobe, Japan) and $500 \mathrm{~g}$ alfalfa (Medicago sativa) meal twice a day $(09: 00$ and $17: 00)$. The diet contained a rclatively large amount of lucerne meal to stimulate hind gut fermentation. Water and a mineral block were always available. Digesta $(c a .200 \mathrm{~m} l)$ were sampled $2 \mathrm{~h}$ after the morning feed and squeezed through a nylon mesh of $250 \mu \mathrm{m}$ pore. Subsamples of the filtrate were centrifuged in nitrogen-filled tubes at $25,000 \times \mathrm{g}$ for $10 \mathrm{~min}$ at $4^{\circ} \mathrm{C}$. Each resultant pellet was washed twice with one of following buffers : $0.05 \mathrm{M}$ MES (2- $(N$-morphorino) ethanesulfonic acid) at pH 5.2 and 6.0 and $0.05 \mathrm{M}$ HEPES ( $N$-2-hydroxy-etylpiperazine- $N$-2-ethanesulfonic acid) at $\mathrm{pH} 7.2$. One centrifuge tube was allotted to each of the three buffers. Bacterial pellets were finally suspended in the same washing buffers of which the volumes were twice as much as original filtrate volume so that bacterial concentration was adjusted to be half that of the original digesta. A portion $(1 \mathrm{ml})$ of washed cell suspension was introduced into an anaerobic culture tube (Aluminum seal type; Bellco Biotechnology, Vineland, NJ, USA) in which was placed $5 \mathrm{~m} l$ of buffer of different $\mathrm{pH}$ containing $20 \mathrm{mM}$ (final concentration) of sodium sulfate and $50 \mathrm{mM}$ (final concentration) of lithium lactate. The following three buffers with 14 different $\mathrm{pHs}$ were used : $0.05 \mathrm{M}$ citrate buffer (pH 4.5, 5.0, 5.2, 5.5), 0.05 M MES (pH 5.2, 5.5, 6.0, $6.2,6.4,6.6$ ), and $0.05 \mathrm{M}$ HEPES (pH 6.8, 7.0, 7.2,
7.4). Washed cell suspensions prepared with MES ( $\mathrm{pH}$ 5.2), MES ( $\mathrm{pH} 6.0$ ) and HEPES ( $\mathrm{pH} 7.2$ ) were introduced into the tubes with respectively citrate, MES, and HEPES buffer. The buffers were boiled and gassed with $\mathrm{O}_{2}$-free nitrogen before use. Three culture tubes were allotted for each buffer $(3 \times 14=52$ tubes in total) and one of the three tubes was used for the measurement of the $\mathrm{pH}$ at zero time using a card type $\mathrm{pH}$ meter (C-1, Horiba). Culture tubes were filled with $\mathrm{O}_{2}$-free nitrogen and closed with butyl rubber septa and aluminum caps. When hydrogen was used as the electron donor, lithium lactate was omitted and nitrogen was replaced by hydrogen. Tubes were incubated at $37^{\circ} \mathrm{C}$ for $12 \mathrm{~h}$ and activity was terminated by the introduction of $1 \mathrm{~m} l$ of 6 $\mathrm{N} \mathrm{HCl}$. Incubation continued for another 30 $\min$ at $37^{\circ} \mathrm{C}$, then a portion $(0.5 \mathrm{ml})$ of head space gas was sampled by a gas-tight syringe. The gas was analyzed for acid volatile sulfur compounds (AVS) using a gas chromatograph (GC-14 B, Shimadzu) fitted with a flame photometric detector. AVS were separated by DB23 capillary column $(0.25 \mathrm{~mm} \times 25 \mathrm{~m}$, J \& W Scientific, Folsom, CA, USA) at $80^{\circ} \mathrm{C}$ with nitrogen as a carrier gas. Split injection $(1 / 100)$ was done at $200^{\circ} \mathrm{C}$. Quantification of hydrogen sulfide was performed using a C-R6 A integrator (Shimadzu). This followed the official analytical method for environmental samples established by the Environment Agency of the Japanese government ${ }^{10)}$ except for the GC conditions.

The concentrations of organic acids in the 12 $\mathrm{h}$ culture were determined by ion exclusion HPLC $^{16}$. Briefly, organic acids were separated by two tandem Waters Organic acid columns $\left(30 \mathrm{~cm} \times 2\right.$, Nihon Waters, Osaka) at $80^{\circ} \mathrm{C}$ with an isocratic elution of $p$-toluene sulfonic acid aqueous solution.

The results suggested that day to day variation was insignificant; accordingly the results from three incubations in three weeks were combined. 


\section{Results and Discussion}

Figures 1 and 2 show the $\mathrm{pH}$ dependence of dissimilatory sulfate reduction in pig cecal flora for, respectively, the two electron donors, hydrogen gas and lactate. Hydrogen sulfide production was observed between $\mathrm{pH} 5.5$ and 7.4 with both electron donors. This $\mathrm{pH}$ range

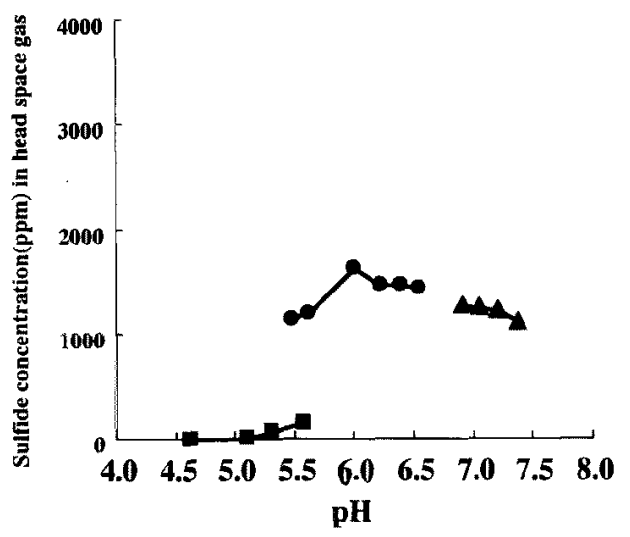

Fig. 1. Hydrogen sulfide production (ppm) by pig caecal flora incubated in vitro with hydrogen. Citrate buffer (pH 4.5-5.5)

- MES buffer (pH 5.2-6.6) A HEPES buffer (pH 6.8-7.4)

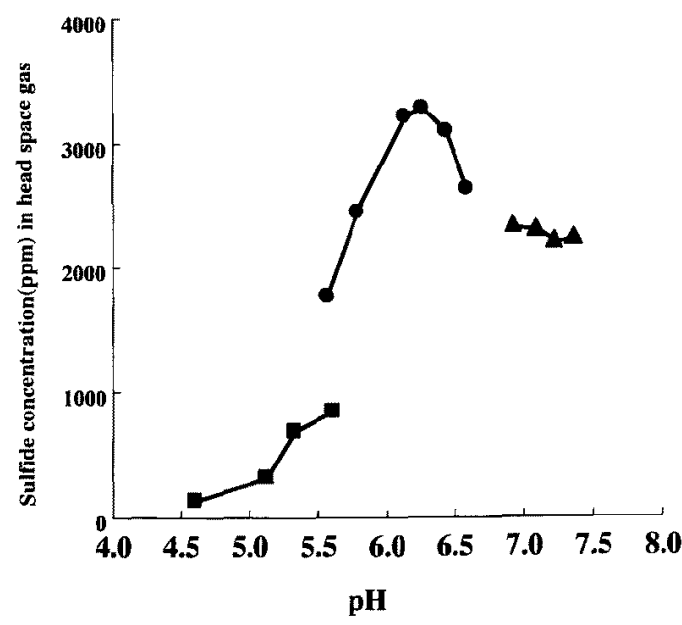

Fig. 2. Hydrogen sulfide production (ppm) by pig caecal flora incubated in vitro with lactate.

Citrate buffer ( $\mathrm{pH} 4.5-5.5) \quad$ MES buffer $(\mathrm{pH}$ 5.2-6.6) A HEPES buffer ( $\mathrm{pH} \mathrm{6.8-7.4)}$ corresponds to the growth $\mathrm{pH}$ of colonic SRB, mainly Desulfovibrio spp. ${ }^{6}$. The $\mathrm{pH}$ optimum for dissimilatory sulfate reduction with hydrogen gas (around $\mathrm{pH} 6.0$ ) was slightly acidic than that with lactate (pH 6.1-6.4). Such a small difference was somewhat unexpected, because the equations of dissimilatory sulfate reduction suggest that proton concentration might inversely affect hydrogen sulfide production with hydrogen and lactate. According to Thauer et al. ${ }^{13}$, following equations can be proposed for the dissimilatory sulfate reduction with hydrogen or lactate ;

$$
\begin{gathered}
4 \mathrm{H}_{2}+\mathrm{H}^{+}+\mathrm{SO}_{4}{ }^{2-} \rightarrow \mathrm{HS}^{-}+4 \mathrm{H}_{2} \mathrm{O} \\
\left(\Delta \mathrm{G}^{\mathrm{o}^{\circ}}=-151.9 \mathrm{KJ} / \text { reaction }\right) \\
2 \mathrm{CH}_{3} \mathrm{CH}(\mathrm{OH}) \mathrm{COO}^{-}+\mathrm{SO}_{4}{ }^{2} \rightarrow \mathrm{HS}^{-}+\mathrm{H}^{+} \\
+2 \mathrm{HCO}_{3}{ }^{-}+2 \mathrm{CH}_{3} \mathrm{COO}^{-} \\
\left(\Delta \mathrm{G}^{0^{\prime}}=-160.3 \mathrm{KJ} / \text { reaction }\right)
\end{gathered}
$$

Equations (1) and (2) suggest that dissimilatory sulfate reduction with hydrogen gas may proceed more efficiently under acidic conditions and vise versa for that with lactate. As the mixed cecal population was used in this experiment, the competition and cooperation among various bacteria may complicate the situation making the $\mathrm{pH}$ effect on sulfate reduction less clear than expected. However apparently the pH optima of dissimilatory sulfate reduction were acidic, between $\mathrm{pH} 6.0$ and $\mathrm{pH}$ 6.4, at least for the two major electron donors in the pig cecal microflora. Apparent lactate consumption during $12-\mathrm{h}$ incubation is shown in Fig. 3. Maximal lactate consumption was recorded at pH 5.7 (Fig. 3), slightly lower than the $\mathrm{pH}$ at which maximal hydrogen sulfide production with lactate was recorded (pH 6.2, Fig. 2). Since apparent acctate production (Fig. 3) showed a similar $\mathrm{pH}$ dependence profile to that of sulfide production (Fig. 2), acetate was therefore suggested to be produced mainly from lactate by sulfate reducers in this experiment.

The $\mathrm{pH}$ optima of sulfate reduction in pig cecal digesta may be placed around $\mathrm{pH} 6.2$ that are similar to those observed in human large intestine $^{9)}$. The $\mathrm{pH}$ of cecal digesta of the 


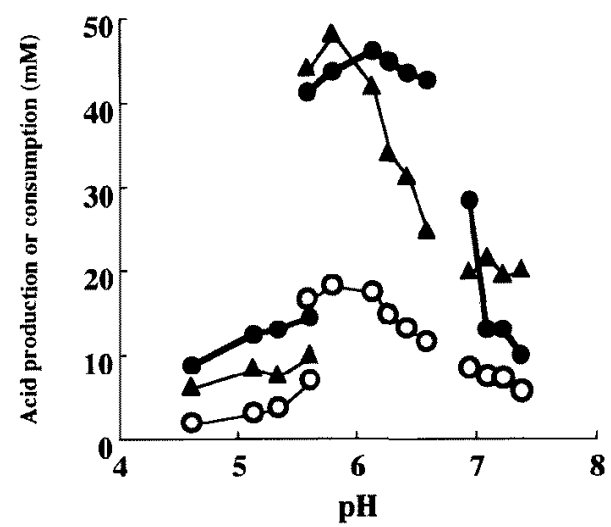

Fig. 3. Acetate and propionate production and lactate consumption (mM) by pig caecal flora incubated in vitro with lactate.

Apparent production of acetate (O) and propionate $(\mathrm{O})$, apparent consumption of lactate $(\boldsymbol{A})$ in the lactate-culture of pig caecal microflora are showm.

Buffers and $\mathrm{pH}$, see text.

experimental pig was 6.6 that was higher than $\mathrm{pH}$ optima of sulfate reduction. Colonic digesta $\mathrm{pH}$ (6.8 to 7.2 ) was higher than that in cecurn (6.7) when pigs were fed only presently used concentrate (Ushida and Ohashi, unpublished). Therefore sulfate reduction seems not to proceed at the maximum efficiency under such condition. However, the use of probiotics such as live Lactobacilli and prebiotics such as oligosaccharide becomes common in the pig industry as evidenced by commercialization of probiotics- or prebioticscontaining concentrates. Since the production of lactate provides a major electron donor to the colonic sulfate reducers, a dietary supplementation of indigestible oligosaccharides might be expected to cause hydrogen sulfide production in the colon. Such oligosaccharides are considered to be bifidogenic ${ }^{33}$ because they promote accumulation of lactic acid in the large intestine ${ }^{8)}$. A concomitant decrease in $\mathrm{pH}$ has been observed after the ingestion of indigestible oligosaccharides $^{8)}$. If digesta $\mathrm{pH}$ is decreased lower than 5.5 due to lactate accumulation, sulfate reduction will be substantially inhibited. If digesta $\mathrm{pH}$ ranges around 6.2 , sulfate reduction will be stimulated. This point requires further elucidation.

\section{Acknowledgment}

The authors wish to thank Dr. G.J. Faichney for his critical reading of the manuscript and valuable suggestions. They also thank Dr. K. Hara, Mr. K. Mikuni and Dr. K. Fujita (Carbohydrate Research Laboratory, Ensuiko Sugar Refining Co. Ltd., Yokohama, Japan) for the discussion. This work was supported by a grant from Ensuiko Sugar Refining Co. Ltd.

\section{References}

1) Christl SU, Gibson GR, Cummings JH. Role of dietary sulfate in the regulation of methanogenesis in the human large intestine. Gut, 33 : 1234-1238. 1992.

2) Cummings JH, Pomare EW, Branch WJ, Naylor CPE, Macfarlane GT. Short chain fatty acids in human large intestine, portal, hepatic and venous blood. Gut, $28: 1221-1227.1987$.

3) Delzenne NM, Roberfroid MR. Physiological Effects of non-digestible oligosaccharides. Lebensm. Wiss. Technol., $27: 1-6.1994$.

4) Fauque GD. Ecology of sulfate-reducing bacteria. In : Sulfate-reducing Bacteria. (Barton LL ed.) 217-242. Plenum Press. New York, 1995.

5) Gibson GR, Cummings JH, Macfarlane GT. Use of a three-stage continuous culture system to study the effect of mucin on dissimilatory sulfate reduction and methanogenesis by mixed populations of human gut bacteria. Appl. Environ. Microbiol., 54 : 2750-2755. 1988.

6) Gibson GR, Cummings JH, Macfarlane GT. Growth and activities of sulfate-reducing bacteria in gut contents of healthy subjects and patients with ulcerative colitis. FEMS Microbiol. Ecol., 86 : 1003-1111. 1991.

7) Gibson GR, Macfarlane GT, Cummings JH. Sulfate reducing bacteria and hydrogen me tabolism in the human large intestine. Gut, 34 : 437-439. 1993.

8) Hoshi S, Sakata T, Mikuni K, Hashimoto H, Kimura S. Galactosylsucrose and xylosylfructoside alter digestive tract size and concentrations of cecal organic acids in rats fed 


\title{
$\mathrm{pH}$ and Cecal Sulfate Reduction
}

diets containing cholesterol and cholic acid. J. Nutr., $124: 52-60.1994$.

9) Macfarlane GT, Gibson GR, Cummings JH. Comparison of fermentation reactions in different regions of the human colon. J. Appl. Bacteriol., 72 : 57-64. 1992.

10) Nihon Kankyou Eisei Center. Tokutei akushu busshitsu sokutei manual. 25-61. Nihon Kankyo Eisei Center. Kawasaki-shi. 1996.

11) Pfennig $N$, Widdel $F$, Trüper $H G$. The dissimilatory sulfate-reducing bacteria. In : The Prokaryotes: A Handbook on the Habitats, Isolation, and Identification of Bacteria. 1st ed, vol. I. (Starr MP, Stolp H, Trüper HG, Balows A, Schlegel H G eds.) 926-940. Springer -Verlag. Heiderberg. 1981.

12) Stecher PG, Windholtz M, Leahy DS, Bolton DM, Eaton LG. The merk index, 8th ed. Merck and Co. Rahway, N.J. USA. 1968.

13) Thauer RK, Jungermann K, Decker K. Energy conservation in chemotrophic anaerobic bacteria. Bacteriol. Rev., 41 : 100-180. 1977.

14) Tuttle JH, Dugan PR, MacMillan CB, Randles Cl. Microbial dissimilatory sulfur cycle in acid mine water. J. Bacteriol., 97 : 594-602. 1969.

15) Ushida $K$, Ohashi $Y$, Tokura $M$, Miyazaki $K$, Kojima $Y$. Sulfate reduction and methanogenesis in the ovine rumen and porcine cecum: A comparison of two microbial ecosystems. Deut. Tierartzl. Woch., $102: 154-156$. 1995.

16) Ushida $K$, Sakata $T$. Effect of $\mathrm{pH}$ on oligosaccharide fermentation by porcine cecal digesta. Anim. Sci. Technol. (Jpn.), $69: 100-107$. 1998.

\section{ブタ盲腸内硫酸還元の $\mathrm{pH}$ 依存性}

\author{
牛田一成・福定伸也・小島洋一
}

京都附立大学農学部, 京都方左京区 606-8522

異化型硫酸還元の結果，大腸で発生する硫化水菜は生体にとって有害であり，発生を制御する必要が 指摘されているが, 大腸における硫酸還元菌の生理や生態はあまり知られていない。この実験では, 大 腸で起こる異化型硫酸還元の $\mathrm{pH}$ 依存性について知ることを目的とした。ブタ盲腸液より調整した細菌 想濁液を $\mathrm{pH} 4.5$ から 7.4 の範囲で 14 段階に調整した緩衝液中で 12 時問培養し, 発生した硫化水素を定 量した。このとき硫酸イオンと電子供与体（乳酸あるいは水素）は十分量供給した。至適 $\mathrm{pH}$ は乳酸基質 の場合 6.1 6.4で，水菜基質の場合の 6.0 よりやや高かった。

日畜会報，69(6)：571-575, 1998 